\title{
Lima Ekstrak Tumbuhan untuk Menekan Infeksi Bean common mosaic virus pada Tanaman Kacang Panjang
}

\author{
Five Plant Extracts for Suppressing \\ Bean common mosaic virus Infection on Yard Long Bean \\ Lulu Kurnianingsih, Tri Asmira Damayanti* \\ Institut Pertanian Bogor, Bogor 16680
}

\begin{abstract}
ABSTRAK
Bean common mosaic virus (BCMV) merupakan virus penting pada tanaman kacang-kacangan yang termasuk sulit dikendalikan. Penelitian ini bertujuan menguji potensi ekstrak tumbuhan dalam menekan BCMV. Ekstrak tumbuhan yang digunakan berasal dari daun bunga pagoda, bayam duri, bunga pukul empat, Chenopodium amaranticolor, dan sambiloto. Ekstrak kasar disemprotkan ke daun kacang panjang dan virus diinokulasi secara mekanis sehari kemudian. Tanaman perlakuan ekstrak daun bayam duri menunjukkan variasi gejala dari mosaik ringan, mosaik berat, malformasi, dan kerdil. Perlakuan ekstrak lainnya menunjukkan gejala mosaik ringan ataupun tidak bergejala. Kejadian penyakit tertinggi sampai terendah berturut-turut ditunjukkan oleh perlakuan ekstrak daun bayam duri (70\%), daun bunga pukul empat (10\%), dan sambiloto (10\%), sedangkan daun bunga pagoda serta $C$. amaranticolor tetap sehat. Kejadian penyakit berkorelasi positif dengan keparahan penyakit dan penghambatan virus. Kecuali bayam duri, keempat ekstrak tanaman berpotensi sebagai agens penginduksi ketahanan sistemik terhadap BCMV.
\end{abstract}

Kata kunci: BCMV, ekstrak tanaman, kacang panjang

\begin{abstract}
Bean common mosaic virus (BCMV) is one of major virus infecting legumes and is difficult to manage. Utilization of plant extracts as systemic resistance inducer against virus is needed to study. The aim of the research is to evaluate the potency of five leaf extracts, i.e. from pagoda flower, spiny amaranth, four o'clock flower, Chenopodium amaranticolor, and herba andrographitis against BCMV. The effectiveness of leaf extracts were tested by spraying yard long bean leaves. Plants treated by spine spinach shown varied symptoms, while other treatments showed mild mosaic up to symptomless. The highest to lowest of disease incidence was showed by crude leaf extract of spine spinach $(70 \%)$, four o'clock (10\%), herba andrographitis $(10 \%)$, while C. amaranticolor and pagoda are still uninfected. These results had positive correlation to disease severity and virus inhibition. Four of five tested leaf extracts, except spine spinach, showed their potency as systemic resistance inducer against BCMV.
\end{abstract}

Key words: BCMV, plant extract, yard long bean

*Alamat penulis korespondensi: Departemen Proteksi Tanaman, Fakultas Pertanian, Institut Pertanian Bogor, Kampus Darmaga, Jalan Kamper, Bogor 16680

Tel: 0251-8629364, Faks: 0251-8629362, Surel: triadys@yahoo.com 


\section{PENDAHULUAN}

Kacang panjang merupakan tanaman hortikultura yang memiliki nilai ekonomi penting di Indonesia, namun produktivitas kacang panjang sangat rendah, yaitu 2-3 ton/ha (Kariada et al. 2003). Salah satu gangguan penyakit yang penting pada kacang panjang disebabkan oleh infeksi Bean common mosaic virus (BCMV). Penyakit mosaik kacang panjang menyebabkan kerugian sebesar $65.87 \%$ (Kuswanto et al. 2007) dan BCMV dilaporkan sebagai salah satu penyebab mosaik kuning kacang panjang yang menginfeksi secara tunggal ataupun bersama Cucumber mosaic virus (CMV) di Jawa Barat (Damayanti et al. 2009). BCMV dapat terbawa benih hingga 83\% (Drijfhout 1977) dan menyebar efisien melalui kutudaun. Penggunaan varietas yang tahan dan benih bebas virus menjadi salah satu upaya yang efektif dalam mengendalikan BCMV, namun hingga saat ini tidak banyak tersedia kultivar komersial dengan sifat tahan terhadap virus tersebut.

Ketahanan sistemik dari suatu tanaman dapat diaktifkan dengan menginduksi gen-gen ketahanan yang terdapat di dalam tanaman dengan memanfaatkan agens penginduksi ketahanan (Kuc 1987). Salah satu agens penginduksi ketahanan sistemik tanaman ialah ekstrak tumbuhan (Verma et al. 1998). Ekstrak daun bayam duri (Amaranthus spinosus), daun bunga pukul empat(Mirabilisjalapa), dan daun bunga pagoda (Clerodendrum paniculatum) dilaporkan dapat menginduksi ketahanan sistemik terhadap patogen antraknosa dan CMV pada cabai (Suganda 2000; Hersanti 2003; Anggraini 2007). Ekstrak tanaman lainnya seperti Chenopodium amaranticolor dilaporkan memiliki aktivitas antivirus untuk Tobacco mosaic virus (TMV) dan antitumor untuk tumor Ehrlich (EA) (De Oliveira et al. 1993), namun belum ada laporan sambiloto yang dapat menginduksi ketahanan sistemik tanaman terhadap infeksi patogen. Sambiloto banyak dimanfaatkan untuk pengobatan penyakit manusia (Yufri et al. 1996).

Pemanfaatan ekstrak tanaman yang bermanfaat sudah dilakukan untuk kepen- tingan kesehatan pada manusia, tetapi masih sedikit yang dimanfaatkan dalam proteksi tanaman. Oleh karena itu, upaya eksplorasi berbagai jenis tanaman potensial perlu dimanfaatkan untuk pengendalian patogen, termasuk virus. Penelitian ini bertujuan untuk menguji keefektifan ekstrak tumbuhan untuk menekan BCMV.

\section{BAHAN DAN METODE}

\section{Perbanyakan Inokulum}

Inokulum BCMV merupakan koleksi Laboratorium Virologi Tumbuhan IPB, yang diisolasi dari dan diperbanyak pada tanaman kacang panjang yang berasal dari isolat Bogor. Daun muda yang bergejala digunakan sebagai inokulum. BCMV yang digunakan telah dikonfirmasi runutan asam nukleatnya melalui DNA sequencing. Kacang panjang umur 7 hari setelah tanam (HST) diinokulasi secara mekanis dengan BCMV dan dipelihara dalam rumah kasa.

\section{Penanaman Kacang Panjang}

Kacang panjang kultivar Parade ditanam dalam pot yang berisi medium tanam tanah dan pupuk kandang dengan perbandingan 2:1. Setiap pot diberi ajir untuk memudahkan tanaman tumbuh menjalar dan diikat dengan menggunakan tali rafia.

\section{Pembuatan dan Perlakuan Ekstrak Tanaman}

Ekstrak kasar daun tumbuhan bunga pagoda, bayam duri, bunga pukul empat, $C$. amaranticolor, dan sambiloto dibuat dengan menggerus daun dalam air steril $(1: 10 \mathrm{~b} / \mathrm{v})$ dan disaring. Ekstrak tanaman disemprot merata ke seluruh daun kacang panjang yang berumur 9 HST sehari sebelum inokulasi virus. Tanaman kontrol sehat disemprot air dan kontrol sakit diinokulasi dengan virus tanpa perlakuan ekstrak tanaman.

\section{Inokulasi BCMV pada Tanaman Kacang Panjang \\ Kacang panjang yang berumur 10 HST diinokulasi dengan BCMV secara mekanis.}


Inokulum virus disiapkan dengan menggerus daun sakit dalam bufer fosfat 1:10 b/v. Inokulasi virus dilakukan dengan cara mengoleskan inokulum pada daun pertama tanaman kacang panjang yang telah ditaburi carborundum 600 mesh.

Percobaan dirancang menggunakan rancangan acak lengkap (RAL) terdiri atas 7 perlakuan, dan tiap perlakuan terdiri atas 10 tanaman sebagai ulangan. Perlakuan terdiri atas kontrol sehat (kontrol negatif), kontrol terinfeksi BCMV tanpa perlakuan ekstrak tanaman (kontrol positif), dan perlakuan ekstrak tumbuhan (5 jenis ekstrak tumbuhan). Data diolah dengan analisis sidik ragam yang dilanjutkan dengan uji selang berganda Duncan pada taraf nyata $\alpha 5 \%$.

\section{Pengamatan}

Pengamatan dilakukan terhadap tipe gejala, masa inkubasi (hasil rata-rata dari 10 tanaman uji), kejadian penyakit, keparahan penyakit, area under diseases progress curve (AUDPC) pada 2, 4, 6, dan 8 minggu setelah inokulasi (MSI), dan akumulasi virus. Deteksi virus dilakukan pada daun tanaman yang berumur 4 MSI secara serologi dengan antigen coated plate-enzymed linked immunosorbent assay (ACP-ELISA) menggunakan antiserum Potyvirus (DSMZ). Akumulasi virus dikuantifikasi dengan ELISA reader pada panjang gelombang $405 \mathrm{~nm}$. Kejadian penyakit ditentukan dengan menggunakan rumus:

$$
\mathrm{KP}=\mathrm{n} / \mathrm{N} \times 100 \% \text {, dengan }
$$

$\mathrm{n}$, jumlah tanaman bergejala; $\mathrm{N}$, total jumlah tanaman uji.

Keparahan penyakit ditentukan dengan menggunakan skala sebagai berikut:

0 , tanaman tidak menunjukkan gejala virus;

1, tanaman menunjukkan gejala mosaik ringan, dan pemucatan tulang daun (vein clearing);

2, tanaman menunjukkan gejala mosaik sedang;

3, tanaman menunjukkan gejala mosaik berat;

4, tanaman menunjukkan gejala mosaik berat, dengan malformasi daun yang parah, kerdil, atau mati.
Data pengamatan keparahan penyakit digunakan untuk membuat grafik perkembangan penyakit. Total luas area yang berada di bawah kurva perkembangan penyakit (AUDPC) (Strange 2003), dihitung dengan menggunakan rumus:

$$
\text { AUDPC }=\sum_{i=1}^{n}\left[\frac{Y_{i}+Y_{i+1}}{2}\right]\left(t_{i+1}-t_{i}\right) \text {, dengan }
$$

$\mathrm{Y}_{\mathrm{i}}$, data pengamatan ke-i;

$\mathrm{Y}_{\mathrm{i}+1}$, data pengamatan $\mathrm{ke}-\mathrm{i}+1$;

$t_{i}$, waktu pengamatan ke-i;

$t_{i+1}$, waktu pengamatan ke- $i+1$

Persentase penghambatan BCMV karena perlakuan ekstrak tumbuhan dihitung berdasarkan pada rumus berikut ini.

$$
\mathrm{P}=\frac{\text { AUDPC }_{\text {kontrol positif }}-\mathrm{AUDPC}_{\text {perlakuan }}}{\mathrm{AUDPC}_{\text {kontrol positif }}} \times 100 \%
$$

\section{HASIL}

\section{Masa Inkubasi}

Masa inkubasi BCMV pada tanaman yang diberi ekstrak daun bayam duri memiliki rata-rata masa inkubasi terpanjang (5.5 HSI) dibandingkan dengan perlakuan ekstrak daun bunga pukul empat dan sambiloto. Kedua perlakuan menunjukkan masa inkubasi nyata lebih cepat jika dibandingkan dengan perlakuan kontrol. Pada kedua perlakuan dari 10 tanaman uji, hanya satu tanaman bergejala dengan masa inkubasi 6 HSI sehingga rata-rata masa inkubasinya menjadi 0.6 HSI (kurang dari 1 HSI). Perlakuan ekstrak daun bunga pagoda dan $C$. amaranticolor tidak menunjukkan gejala sampai akhir pengamatan sehingga tidak ada masa inkubasi yang tercatat (Tabel 1).

\section{Tipe Gejala}

Inokulasi BCMV menghasilkan gejala bermacam-macam (Tabel 1). Tanaman yang diberi perlakuan ekstrak daun bayam duri menunjukkan gejala mulai dari mosaik ringan, mosaik berat, malformasi hingga kerdil; sedangkan perlakuan ekstrak tumbuhan lainnya hanya menimbulkan gejala mosaik ringan ataupun tidak bergejala. 


\section{Kejadian Penyakit}

Tanaman yang diberi perlakuan ekstrak daun bunga pagoda dan C. amaranticolor tidak terinfeksi virus sampai akhir pengamatan, sedangkan perlakuan ekstrak daun bunga pukul empat dan sambiloto menyebabkan satu tanaman yang menunjukkan gejala terinfeksi virus. Kejadian penyakit pada tanaman yang diberi ekstrak daun bayam duri mencapai $70 \%$ (Tabel 2).

\section{Keparahan Penyakit}

Perlakuan ekstrak tumbuhan, kecuali perlakuan ekstrak daun bayam duri, secara nyata menurunkan keparahan penyakit. Di antara perlakuan ekstrak tumbuhan, keparahan penyakit tertinggi ditunjukkan oleh perlakuan ekstrak daun bayam duri, sedangkan yang terendah ditunjukkan oleh perlakuan ekstrak daun bunga pagoda dan C. amaranticolor, namun tidak berbeda nyata dibandingkan dengan perlakuan ekstrak daun bunga pukul empat dan sambiloto (Tabel 2).

\section{Deteksi Virus dengan ELISA}

Hasil nilai absorban ELISA (NAE) menunjukkan bahwa perlakuan ekstrak daun bunga pagoda dan $C$. amaranticolor tidak terdeteksi adanya virus; NAE tidak berbeda nyata dengan kontrol negatif (Tabel 2). Perlakuan ekstrak daun bunga pukul empat dan sambiloto serta bayam duri mengandung virus, akan tetapi hasil uji menunjukkan ekstrak daun bunga pukul empat dan sambiloto berbeda nyata dengan kontrol positif, sedangkan perlakuan ekstrak bayam duri tidak berbeda nyata dengan kontrol positif (Tabel 2).

Tabel 1 Pengaruh perlakuan terhadap masa inkubasi virus mosaik dan tipe gejala

\begin{tabular}{lcc}
\hline Perlakuan & Masa inkubasi (HSI) & Tipe gejala* \\
\hline Kontrol negatif & - & Tidak ada gejala \\
Kontrol positif & $10.5 \pm 5.6 \mathrm{a}^{* *}$ & Mr, Mb, Md \\
Daun bunga pagoda & - & Tidak ada gejala \\
Daun bayam duri & $5.5 \pm 4.8 \mathrm{~b}$ & $\mathrm{Mr}, \mathrm{Mb}, \mathrm{Md}, \mathrm{K}$ \\
Daun bunga pukul empat & $0.6 \pm 1.9 \mathrm{c}$ & $\mathrm{Mr}$ \\
Chenopodium amaranticolor & - & Tidak ada gejala \\
Sambiloto & $0.6 \pm 1.9 \mathrm{c}$ & $\mathrm{Mr}$ \\
\hline
\end{tabular}

*Mr, mosaik ringan; $\mathrm{Mb}$, mosaik berat; $\mathrm{Md}$, malformasi daun; $\mathrm{K}$, kerdil

**angka yang diikuti huruf berbeda menunjukkan hasil berbeda nyata pada uji selang ganda Duncan $\alpha 0.05$

HSI, hari setelah inokulasi

- , tidak ada

Tabel 2 Pengaruh perlakuan terhadap kejadian penyakit (KP), keparahan, dan Hasil ELISA

\begin{tabular}{lrrrrcc}
\hline Perlakuan & \multirow{2}{*}{ KP $(\mathrm{n} / \mathrm{N}) *(\%)$} & \multirow{2}{*}{ Keparahan } & \multicolumn{2}{c}{ Hasil ELISA** } \\
\cline { 5 - 7 } & & & & NAE & Reaksi \\
\hline Kontrol negatif & $0 / 10$ & $(0)$ & $0.0 \pm 0.0 \mathrm{~b} * * *$ & $0.074 \pm 0.013 \mathrm{~b}$ & - \\
Kontrol positif & $10 / 10(100)$ & $2.8 \pm 1.1 \mathrm{a}$ & $2.594 \pm 0.466 \mathrm{a}$ & + \\
Daun bunga pagoda & $0 / 10$ & $(0)$ & $0.0 \pm 0.0 \mathrm{~b}$ & $0.079 \pm 0.023 \mathrm{~b}$ & - \\
Daun bayam duri & $7 / 10$ & $(70)$ & $2.6 \pm 1.8 \mathrm{a}$ & $2.110 \pm 1.433 \mathrm{a}$ & + \\
Daun bunga pukul empat & $1 / 10$ & $(10)$ & $0.2 \pm 0.6 \mathrm{~b}$ & $0.388 \pm 0.963 \mathrm{~b}$ & + \\
Chenopodium amaranticolor & $0 / 10$ & $(0)$ & $0.0 \pm 0.0 \mathrm{~b}$ & $0.080 \pm 0.016 \mathrm{~b}$ & - \\
Sambiloto & $1 / 10$ & $(10)$ & $0.3 \pm 0.9 \mathrm{~b}$ & $0.321 \pm 0.726 \mathrm{~b}$ & + \\
\hline
\end{tabular}

* n, jumlah tanaman yang terinfeksi; $\mathrm{N}$, jumlah tanaman yang diamati

**NAE, nilai absorban ELISA. Reaksi positif ditetapkan jika NAE sampel uji dua kali NAE kontrol negatif

***angka yang diikuti huruf yang berbeda pada kolom yang sama menunjukkan hasil berbeda nyata pada uji selang ganda Duncan $\alpha 0.05$ 


\section{AUDPC dan Penghambatan BCMV}

Semua perlakuan ekstrak tanaman, kecuali perlakuan ekstrak bayam duri, menunjukkan nilai AUDPC yang nyata lebih rendah dan persentase penghambatan yang lebih tinggi dibandingkan dengan kontrol positif (Tabel 3). Nilai AUDPC perlakuan ekstrak dari yang terbesar hingga yang terkecil, yaitu perlakuan ekstrak daun bayam duri, sambiloto, bunga pukul empat, $C$. amaranticolor, dan bunga pagoda.

Nilai AUDPC berkorelasi positif dengan persentase penghambatan penyakit. Pada perlakuan ekstrak tumbuhan, persentase penghambatan BCMV yang tertinggi ditunjukkan oleh perlakuan ekstrak daun bunga pagoda dan C. amaranticolor $(100 \%)$ dan yang terendah adalah perlakuan ekstrak daun bayam duri (23.1\%) (Tabel 3).

Secara umum, kecuali perlakuan ekstrak bayam duri, aplikasi ekstrak tanaman tidak menghambat pertumbuhan tanaman kacang panjang (data tidak ditampilkan).

\section{PEMBAHASAN}

Penggunaan ekstrak tumbuhan merupakan salah satu upaya yang perlu dikaji untuk mendapatkan salah satu cara yang dapat mengendalikan BCMV. Setyastuti (2008) melaporkan sembilan kultivar kacang panjang komersial menunjukkan ketahanan yang rendah terhadap BCMV.

Perlakuan ekstrak tumbuhan mampu menekan kejadian penyakit dan keparahan infeksi BCMV, kecuali perlakuan ekstrak daun bayam duri. Dari hasil penelitian ini, perlakuan ekstrak daun bayam duri tidak berpengaruh terhadap infeksi BCMV, berbeda dengan laporan Hersanti (2003) yang mengemukakan bahwa bayam duri mampu menekan infeksi CMV pada cabai dengan penghambatan sebesar $72.48 \%$. Hal ini menunjukkan bahwa ekstrak bayam duri memiliki kemampuan menekan virus dengan keefektifan yang berbeda, bergantung pada spesies virus dan tanaman inang.

Rendahnya keparahan dan akumulasi virus pada perlakuan bunga pagoda dan $C$. amaranticolor menunjukkan potensi kedua tanaman sebagai penginduksi ketahanan sistemik tanaman kacang panjang. Mekanisme induksi ketahanan sistemik kacang panjang oleh perlakuan ekstrak daun bunga pagoda dan C. amaranticolor belum diketahui dan masih perlu diteliti lebih lanjut. Namun, Verma et al. (1998) melaporkan senyawa aktif berupa protein berukuran $34 \mathrm{kDa}$ dalam ekstrak daun bunga pagoda dapat menyebabkan daun tembakau menjadi imun terhadap virus. Kemampuan ekstrak daun C. amaranticolor menekan BCMV menunjukkan bahwa tanaman ini mengandung inhibitor virus dan memiliki aktivitas antivirus (De Oliveira et al. 1993).

Perlakuan ekstrak bunga pukul empat juga mampu menekan BCMV, hal ini kemungkinan karena senyawa aktif bunga pukul empat yang disebut sebagai protein antivirus dan dikenal sebagai ribosome inactivating protein (RIPs). RIPs juga terdapat pada ekstrak akar dan daun M. jalapa dan disebut sebagai Mirabilis antiviral protein (MAP) (Verma et al. 1998). MAP dapat mencapai daerah aktif ribosom terlebih dahulu sehingga dapat mencegah

Tabel 3 Hubungan perlakuan, nilai AUDPC dan persentase penghambatan BCMV

\begin{tabular}{lrc}
\hline Perlakuan & \multicolumn{1}{c}{ AUDPC } & Persen penghambatan \\
\hline Kontrol negatif & $0.0 \pm 0.0 \mathrm{~b}^{*}$ & $100.0 \pm 0.0 \mathrm{a} \mathrm{a}^{* *}$ \\
Kontrol positif & $15.6 \pm 5.8 \mathrm{a}$ & $0.0 \pm 37.2 \mathrm{~b}$ \\
Bunga pagoda & $0.0 \pm 0.0 \mathrm{~b}$ & $100.0 \pm 0.0 \mathrm{a}$ \\
Bayam duri & $12.0 \pm 8.4 \mathrm{a}$ & $23.1 \pm 53.6 \mathrm{~b}$ \\
Bunga pukul empat & $1.2 \pm 3.8 \mathrm{~b}$ & $92.3 \pm 24.3 \mathrm{a}$ \\
Chenopodium amaranticolor & $0.0 \pm 0.0 \mathrm{~b}$ & $100.0 \pm 0.0 \mathrm{a}$ \\
Sambiloto & $1.4 \pm 4.4 \mathrm{~b}$ & $91.0 \pm 28.4 \mathrm{a}$
\end{tabular}

*,** angka yang diikuti huruf yang berbeda pada kolom yang sama menunjukkan hasil berbeda nyata pada uji selang ganda Duncan $\alpha 0.05$ 
infeksi virus pada tahap awal sebelum virus mengalami deenkapsidasi (Vivanco et al. 1999).

Jika dibandingkan dengan efektivitasnya terhadap CMV pada tanaman cabai, perlakuan bunga pukul empat dan bunga pagoda dalam penelitian ini menunjukkan efektivitas menghambat infeksi BCMV (92.3\% dan 100\%), sedangkan terhadap CMV hanya mencapai $82.6 \%$ (bunga pagoda) dan $75.4 \%$ (bunga pukul empat) (Hersanti 2003). Hal ini menunjukkan bahwa ekstrak tumbuhan yang sama menunjukkan efektivitas yang berbeda terhadap virus yang berbeda.

Perlakuan ekstrak daun sambiloto juga menunjukkan persentase penghambatan virus yang tinggi dan diduga memiliki senyawa aktif yang bersifat antivirus, namun belum diketahui jenisnya. Hasil penelitian ini memperkaya informasi akan potensi sambiloto sebagai agens pengendali virus tumbuhan.

Di antara ekstrak tumbuhan yang digunakan dalam penelitian ini, ekstrak daun $C$. amaranticolor, bunga pagoda, bunga pukul empat, dan sambiloto merupakan ekstrak yang berpotensi sebagai penginduksi ketahanan terhadap BCMV.

\section{DAFTAR PUSTAKA}

Anggraini N. 2007. Pengaruh ekstrak daun bunga pukul empat (Mirabilis jalapa L.) terhadap infeksi Cucumber mosaic virus (CMV) pada tanaman cabai (Capsicum annuum L.) [skripsi]. Bogor (ID): Institut Pertanian Bogor.

Damayanti TA, Alabi OJ, Naidu RA, Rauf A. 2009. Severe outbreak of a yellow mosaic disease on the yard long bean in Bogor, West Java. Hayati J Biosci. 16(2):78-82.

De Oliveira MM, Sampaio MR, Noronha AB, Vicente M, Vianna S. 1993. Detection of antiviral and antitumoral fractions of Chenopodium amaranticolor leaf extract. Microbios. 76(309):213-221.

Drijfhout E. 1977. Diseases caused by viruses: Bean common mosaic virus. Di dalam: Drijfhout, editor. Compendium Bean Common Diseases. New York (US): APS Pr. hlm 37-39.
Hersanti. 2003. Pengujian potensi ekstrak 37 spesies tumbuhan sebagai agens penginduksi ketahanan sistemik tanaman cabai merah terhadap Cucumber mosaic virus. J Fitopatol Indones. 7(2):54-58.

Kariada IK, Kartini NL, Aribawa IB. 2003. Pengaruh Pupuk Organik Kascing (POK) dan NPK terhadap Sifat Kimia Tanah dan Hasil Kacang Panjang Di Lahan Kering Desa Pegok Kabupaten Badung. Bali (ID): Balai Pengkajian Teknologi Pertanian Bali. Kuc J. 1987. Plant Immunization and its applicability for disease control. Di dalam: Chet I, editor. Inovative Approaches to Plant Disease Control. New York (US): John Wiley. hlm 225-272.

Kuswanto, Waluyo B, Soetopo L, Afandi A. 2007. Evaluasi keragaman genetik toleransi kacang panjang (Vigna sesquipedalis (L). Fruwirth) terhadap hama aphid. J Akta Agrosia. Edisi Khusus (1):19-25.

Setyastuti L. 2008. Tingkat ketahanan sembilan kultivar kacang panjang terhadap infeksi Bean common mosaic virus (BCMV) [skripsi]. Bogor (ID): Institut Pertanian Bogor.

Strange RN. 2003. Introduction to Plant Pathology. New York (US): John Willey and Sons Ltd.

Suganda T. 2000. Introduction of resistance of red pepper against fruit antracnose by the application of biotic and abiotic inducers. J Agrikultura. 11:72-78.

Verma HN, Baranwal VK, Srisavasta S. 1998. Antiviral substances of plant origin. Di dalam: Hadidi A, Khetarpal RK, Koganezawa H, editor. Plant Virus Disease Control. St. Paul Minnesota (US): APS Pr. hlm 154-162.

Vivanco JM, Querci M, Salazar LF. 1999. Antiviral and antiviroid activity of MAPcontaining extracts from Mirabilis jalapa roots. Plant Dis. 83(12):1116-1121. doi: 10.1094/PDIS.1999.83.12.1116.

Yufri A, Sugiarso NC, Andreanus AAS, Ranti AS. 1996. Uji efek antihistaminergik dari tanaman sambiloto. Warta Tumbuhan Obat Indonesia. 3(1):17-18. 